\title{
Effect of Microwave Treatments on Dimensional Accuracy of Maxillary Acrylic Resin Denture Base
}

\author{
Sabrina PAVAN ${ }^{1}$ \\ João Neudenir ARIOLI Filho ${ }^{1}$ \\ Paulo Henrique DOS SANTOS ${ }^{2}$ \\ Francisco de Assis MOLLO Jr. ${ }^{1}$ \\ ${ }^{1}$ Department of Dental Materials and Prosthodontics, Faculty of Dentistry of Araraquara, \\ São Paulo State University (UNESP), Araraquara, SP, Brazil \\ ${ }^{2}$ Department of Dental Materials and Prosthodontics, Faculty of Dentistry of Araçatuba, \\ São Paulo State University (UNESP), Araçatuba, SP, Brazil
}

\begin{abstract}
Microwave energy has been used as an alternative method for disinfection and sterilization of dental prostheses. This study evaluated the influence of microwave treatment on dimensional accuracy along the posterior palatal border of maxillary acrylic resin denture bases processed by water-bath curing. Thirty maxillary acrylic bases (3-mm-thick) were made on cast models with Clássico acrylic resin using routine technique. After polymerization and cooling, the sets were deflasked and the bases were stored in water for 30 days. Thereafter, the specimens were assigned to 3 groups $(n=10)$, as follows: group I (control) was not submitted to any disinfection cycle; group II was submitted to microwave disinfection for $3 \mathrm{~min}$ at $500 \mathrm{~W}$; and in group III microwaving was done for $10 \mathrm{~min}$ at $604 \mathrm{~W}$. The acrylic bases were fixed on their respective casts with instant adhesive (Super Bonder ${ }^{\circledR}$ ) and the base/cast sets were sectioned transversally in the posterior palatal zone. The existence of gaps between the casts and acrylic bases was assessed using a profile projector at 5 points. No statistically significant differences were observed between the control group and group II. However, group III differed statistically from the others $(\mathrm{p}<0.05)$. Treatment in microwave oven at $604 \mathrm{~W}$ for 10 min produced the greatest discrepancies in the adaptation of maxillary acrylic resin denture bases to the stone casts.
\end{abstract}

Key Words: acrylic resin, disinfection, microwave oven, dimensional accuracy.

\section{INTRODUCTION}

The increased prevalence of some infectious diseases, such as hepatitis B and AIDS, has alerted the public opinion to infection control during dental service (1).

The practice of removable prosthodontics involves use of many instruments and multiuse items that are not easily sterilized or disinfected, including prostheses, impressions and stone casts, which increase potential cross-contamination between dental office and laboratory. Handling of these contaminated or potentially contaminated items may result in selfinoculation and transmission of microorganisms to laboratory personnel or other patients' dentures and prosthetic appliances.

Several studies have recommended various methods to reduce microbial contamination in the dental laboratory. These include use of disinfecting solutions such as wetting agents for pumice, unit doses of pumice or autoclaving pumice and wheels (2). However, these measures have been proved ineffective in preventing contamination completely. Microbial transmission requires blockage by a practical, easy and effective method of dental prosthesis disinfection or sterilization procedures.

Sterilization of acrylic resins by immersion in either $2 \%$ alkaline glutaraldehyde for $10 \mathrm{~min}, 1 \%$ sodium hypochlorite for $10-30 \mathrm{~min}$ or $3 \%$ aqueous formaldehyde for 30 min has been documented (3). These procedures, however, have been proved time-consuming or inappropriate. Microwave energy has currently been used as an alternative to conventional methods, although variations in its efficiency have been reported (4-6).

Rohrer and Bulard (7) showed that microwave energy can easily kill microorganisms on denture acrylic resin surfaces within 15 min of exposure. Webb et al. (8) reported that microwaving dentures at $350 \mathrm{~W}$ during

Correspondence: Dra. Sabrina Pavan, Faculdade de Odontologia de Araraquara, Departamento de Materiais Odontológicos e Prótese, Rua Humaitá, 1680, 14.801-903 Araraquara, SP, Brasil. Tel/Fax: +55-16-3301-6406. e-mail: sabrinapavan@ig.com.br 
6 min may be a more effective method of sterilization than soaking the dentures in $0.02 \%$ sodium hypochlorite for $8 \mathrm{~h}$.

Nevertheless, the dimensional stability of denture acrylic resins undergoing microwave oven disinfection procedures is still controversial. Polyzois et al. (1) reported that dentures submitted to microwaving for up to 16 min presented no dimensional changes, while, Thomas and Webb (9) observed unacceptable dimensional stability in acrylic resin bases after microwave disinfection for $10 \mathrm{~min}$ at $604 \mathrm{~W}$.

The purpose of this study was to evaluate the effects of two microwave disinfection cycles on dimensional accuracy of maxillary acrylic resin denture bases.

\section{MATERIAL AND METHODS}

Thirty cast models poured in type IV dental stone (Vel-Mix; SDS/Kerr, Orange, CA, USA) were obtained from RTV 3120 silicone rubber (D'altomare LTDA, São Paulo, SP, Brazil) impressions of a maxillary arch without alveolar ridge crest imperfections. A $3 \mathrm{~mm}-$ thick acetate base plate (Bio Art, São Carlos, SP, Brazil) was plasticized on each stone cast with a vacuum plasticizer (Bio-Art) to provide an acrylic resin base with uniform thickness. Excesses were trimmed and the plates were fixed to the casts with plasticized wax. The sets were embedded in flasks with dental stone according to conventional flasking procedure.

After $1 \mathrm{~h}$, the flasks were placed in boiling water for 10 min to soften the wax and opened. The bases' plates were discarded and residual wax was removed with liquid detergent and boiling water. Stone surfaces were entirely coated with sodium alginate (S.S. White Dental Products, Rio de Janeiro, RJ, Brazil) for acrylic resin processing.

Clássico acrylic resin (Clássico Dental Products, São Paulo, SP, Brazil) was mixed with 3:1 polymer to monomer volume ratio. In the plastic dough, the resin bulk was homogenized and packed into the flasks under 1250 kgf final packing pressure. The flasks were then placed in strain clamps and submitted to the curing cycle in water bath for $9 \mathrm{~h}$ at $74^{\circ} \mathrm{C}$, following manufacturer's instructions.

After cooling at room temperature, the bases were deflasked and resin excesses were trimmed. The bases were stored in distilled water for 30 days to release stresses that could have been produced during polymerization and deflasking procedures $(10,11)$. Thereafter, the specimens were assigned to 3 groups $(\mathrm{n}=10)$, as follows: group I (control) was not submitted to any disinfection cycle; group II was submitted to microwave disinfection for $3 \mathrm{~min}$ at $500 \mathrm{~W}$; and in group III microwaving was done for $10 \mathrm{~min}$ at $604 \mathrm{~W}$. The cycles were carried out in a microwave oven with a rotating table, power and time control (Continental AW30; Bosh, Manaus, AM, Brazil). During the process, a glass with $150 \mathrm{~mL}$ of water was kept inside the oven to absorb the waves and protect the magnetron.

The treated acrylic resin bases (after cooling at room temperature) and those from the untreated control group were fixed on their corresponding casts with instant adhesive (Super Bonder; Loctite-Henkel, São Paulo, SP, Brazil) to avoid displacement during the cutting procedure. The base/cast sets were sectioned transversally at the posterior palatal zone with a saw in a fixer table under constant water cooling to prevent acrylic resin alterations. To guide and standardize the cuts, the casts had landmarks on both sides of the base in the posterior palatal region, which were previously done in the silicone mold.

Discrepancies between the inner surface of the denture base and the cast were measured using a profile projector (6C; Nikon, Tokyo, Japan) with a traveling stage calibrated to $0.001 \mathrm{~mm}$ at 5 points. Measurements were made at the right marginal limit (A), left marginal limit (B), right ridge crest (C), left ridge crest (D) and palatal midline (E) (Fig. 1).

Data were analyzed statistically by ANOVA and Tukey's test at 5\% significance level.

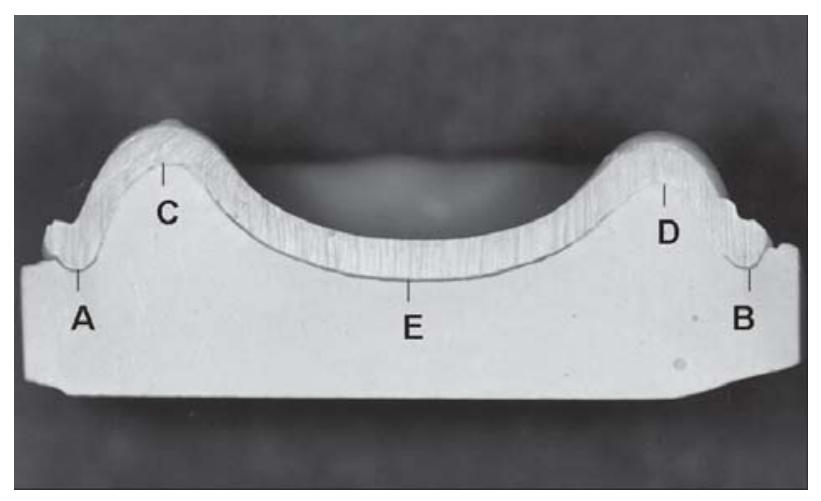

Figure 1. Posterior palatal border view showing the 5 points at which the existence of gaps between the acrylic base and the cast was assessed. Right marginal limit (A); left marginal limit (B); right ridge crest (C); left ridge crest (D); palatal midline (E). 


\section{RESULTS}

Means of discrepancies (in $\mathrm{mm}$ ) between the acrylic bases and the stone casts at each measurement point, for the treatments under study, are given on Table 1.

There was no statistically significant difference ( $>0.05$ ) between group II (microwaving for $3 \mathrm{~min}$ at $500 \mathrm{~W}$ ) and the untreated control group, regarding the adaptation of the acrylic bases to the casts at any of the measurements points. On the other hand, group III (microwaving for $10 \mathrm{~min}$ at $604 \mathrm{~W}$ ) had significantly greater discrepancies in acrylic base adaptation at all measurement points and differed statistically from the other groups $(\mathrm{p}<0.05)$ (Table 1$)$.

When measurement points in the same group were compared, the greatest discrepancies were observed in point B (left marginal limit), which differed statistically from the other points in all groups studied $(p<0.05)$. No statistically significant differences ( $p>0.05$ ) were detected between points $\mathrm{A}$ and $\mathrm{E}$, and points $\mathrm{C}$ and $\mathrm{D}$ (Table 1).

\section{DISCUSSION}

Dentures are submitted to disinfection processes to destroy microorganisms and obtain clean, decontaminated pieces (12), thus preventing crosscontamination between the dental office and laboratory.

The most commonly advised method for disinfection of dentures and prosthetic appliances is soaking in chemical solutions, such as alkaline glutaraldehyde, sodium hypochlorite or aqueous formaldehyde (3). However, studies have shown that many properties of acrylic resins, i.e., roughness, hardness, dimensional stability, color and flexural properties, can be altered after immersion in these solutions $(1,12,13)$.

In 1985, Rorher and Bulard (7) investigated the possibility of using microwave irradiation as an alternative method to sterilize dentures. It has been reported that items contaminated with different microorganisms were fully sterilized after exposure to microwave energy for a few minutes $(4,14,15)$. Bating and Hill (16) observed that microwaving complete dentures was more effective than soaking the pieces in $0.2 \%$ chlorhexidine solution for eradicating the invasive form of Candida albicans organisms. However, there is little information regarding the effect of microwave energy on dimensional accuracy of acrylic resin denture.

In this study, the accuracy of acrylic resin bases was evaluated after disinfection/sterilization procedures in a microwave oven. In groups I and II, only little difference was observed in acrylic base fitting at points $\mathrm{C}$ and $\mathrm{D}$ (Table 1). Variations in measurements of less than $0.040 \mathrm{~mm}-0.150 \mathrm{~mm}$ in the adaptation of the bases to the master stone cast are considered to be clinically insignificant and discrepancies of this magnitude are almost undetectable (17). Discrepancies between the acrylic resin base and the stone cast derive from polymerization shrinkage and stresses produced during flask cooling and may be influenced by several factors, such as polymerization techniques, stress induced during deflasking, palatal geometry and depth $(11,18)$. In all groups, the greatest discrepancies were recorded in point B (Table 1). A possible explanation to the fact

Table 1. Means of discrepancies (mm) between the acrylic bases and the stone casts at each measurement point, for the treatments under study.

\begin{tabular}{lccccc}
\hline & \multicolumn{5}{c}{ Measurement points } \\
\cline { 2 - 6 } Treatments & $\mathrm{A}$ & $\mathrm{B}$ & $\mathrm{C}$ & $\mathrm{D}$ & $\mathrm{E}$ \\
\hline Group I & $0.461 \pm 0.139 \mathrm{Ba}$ & $0.859 \pm 0.240 \mathrm{Aa}$ & $0.009 \pm 0.026 \mathrm{Ca}$ & $0.015 \pm 0.046 \mathrm{Ca}$ & $0.362 \pm 0.077 \mathrm{Ba}$ \\
Group II & $0.496 \pm 0.122 \mathrm{Ba}$ & $0.929 \pm 0.293 \mathrm{Aa}$ & $0.000 \pm 0.000 \mathrm{Ca}$ & $0.020 \pm 0.063 \mathrm{Ca}$ & $0.377 \pm 0.081 \mathrm{Ba}$ \\
Group III & $2.160 \pm 0.501 \mathrm{Bb}$ & $2.722 \pm 0.674 \mathrm{Ab}$ & $0.872 \pm 0.271 \mathrm{Cb}$ & $0.731 \pm 0.444 \mathrm{Cb}$ & $1.869 \pm 0.535 \mathrm{Bb}$ \\
\hline
\end{tabular}

Group I = No disinfection cycle (control); Group II = Microwave (3 min; 500 W); Group III = Microwave (10 min; 604 W). Different uppercase letters indicate statistically significant difference (5\%) in lines (Groups). Different lowercase letters indicate statistically significant difference (5\%) in columns (Points). 
that discrepancies recorded on both sides of the cast (points A and B) differed statistically may be that the dimensional changes taking place during denture base fabrication are not uniform and depend on its location inside the flask (19). Therefore, microwave treatment increases the discrepancies occurred in the marginal flanges according to different inaccuracies promoted by denture processing.

The results of this study showed no statistically significant difference between groups I and II for base adaptation among all measurement points ( $\mathrm{p}>0.05$ ). However, in group III, discrepancy means recorded at points $\mathrm{A}, \mathrm{B}$ and $\mathrm{E}$ increased 3 to 5 times. At points $\mathrm{C}$ and $\mathrm{D}$, discrepancy means were close to zero for groups I and II $(0.009 \mathrm{~mm}$ and $0.015 \mathrm{~mm} ; 0.000 \mathrm{~mm}$ and 0.020 $\mathrm{mm}$, respectively), and around $0.8 \mathrm{~mm}$ for group III. The results of group III showed that disinfection for 10 min increased the discrepancies between the acrylic resin bases and the stone casts.

These findings are consistent with those of a previous study (9), in which unacceptable dimensional changes were observed in maxillary complete dentures after microwave treatment for $10 \mathrm{~min}$ at $604 \mathrm{~W}$. However, the first report on denture microwave sterilization showed that dentures subjected to microwaving for up to 16 min presented no dimensional changes, when adaptation of dentures to die stones was evaluated (7). Burns et al. (20) showed that specimens made from three different acrylic resins maintained excellent stability after $15 \mathrm{~min}$ at $650 \mathrm{~W}$ of microwave irradiation. Another study (1) reported dimensional changes not clinically significant in specimens submitted to 3 and 15 min cycles of microwave disinfection at $500 \mathrm{~W}$.

This study showed that the dimensional accuracy of acrylic resin denture bases after microwave disinfection cycles depends on the power used and time of exposure. Treatment in microwave oven at $604 \mathrm{~W}$ for 10 min produced clinically unacceptable alterations in the adaptation of maxillary acrylic resin denture bases to the stone casts, which contraindicate this time/power setting. On the other hand, microwaving of dentures for $3 \mathrm{~min}$ at $500 \mathrm{~W}$ did not alter their fitting and stability. This time/power setting has been proved adequate for disinfection/sterilization procedures (1). Further studies should evaluate other time/power settings for disinfection or sterilization procedures using microwave energy without affecting negatively the acrylic resin properties.

\section{RESUMO}

A energia por microondas tem sido utilizada como um método alternativo para desinfecção e esterilização de próteses dentárias. Neste estudo, foi avaliada a influência do tratamento com energia de microondas na precisão de adaptação de bases de próteses totais superiores. Trinta bases acrílicas ( $3 \mathrm{~mm}$ de espessura) foram confeccionadas sobre modelos de gesso pela técnica de rotina, utilizando a resina acrílica Clássico. Após a polimerização e resfriamento, foram demufladas e armazenadas em água destilada por 30 dias. Ao final deste período, as bases foram divididas em três grupos: grupo I (controle; sem desinfecção); grupo II tratamento em microondas por $3 \mathrm{~min}$ a $500 \mathrm{~W}$; e grupo III tratamento por $10 \mathrm{~min}$ a $604 \mathrm{~W}$. Em seguida, as bases foram fixadas em seus respectivos modelos de gesso com cola instantânea (Super Bonder), e os conjuntos modelo/base foram seccionados na região palatina posterior. Os desajustes entre as bases e os modelos foram verificados com auxílio de um microscópio comparador linear em cinco pontos. Não houve diferença estatisticamente significante quanto à adaptação das bases entre o grupo I e o grupo II. Contudo, o grupo III apresentou as maiores discrepâncias, diferindo estatisticamente quando comparado aos demais grupos $(\mathrm{p}<0.05)$. O tratamento com energia de microondas utilizando ciclo de $10 \mathrm{~min}$ a $604 \mathrm{~W}$, promoveu as maiores discrepâncias na adaptação das bases acrílicas de próteses totais superiores aos modelos de gesso.

\section{ACKONOWLEDGEMENTS}

The authors acknowledge FAPESP for financial support (Process N. 99/03558-3).

\section{REFERENCES}

1. Polyzois GL, Zissis AJ, Yannikakis SA. The effect of glutaraldehyde and microwave disinfection on some properties of acrylic denture resin. Int J Prosthod 1995;8:150154.

2. Larato DC. Disinfection of pumice. J Prosthet Dent 1967;18:534-535.

3. American Dental Association. Council on prosthetic service and laboratory relations: guideline for infection control in dental office and the commercial dental laboratory. J Am Dent Assoc 1985;110:969-972.

4. Najdovski L, Dragas AZ, Kotnik V. The killing activity of microwaves on some non-sporogenic and sporogenic medically important bacterial strains. J Hosp Infect 1991;19:239-247.

5. Griffith D, Nacey J, Robinson R, Delahunt B. Microwave sterilization of polyethylene catheters for intermittent selfcatheterization. Aust N Z J Surg 1993;63:203-4.

6. Rosaspina S, Anzanel D, Salvatorelli G. Microwave sterilization of enterobacteria. Microbios 1993;76:263-270.

7. Rohrer MD, Bulard RA. Microwave sterilization. J Am Dent Assoc 1985;110:194-198.

8. Webb BC, Thomas CJ, Harty DWS, Willcox MDP. Effectiveness of two methods of denture sterilization. J Oral Rehabil 1998;24:416-423.

9. Thomas CJ, Webb BC. Microwaving of acrylic resin dentures. 
Eur J Prosthod Restor Dent 1995;3:179-182.

10. Braden M. The absorption of water by acrylic resins and other materials. J Prosthet Dent 1964;14:307-316.

11. Sykora O, Sutow EJ. Posterior palatal seal adaptation: influence of processing technique, palate shape and immersion. J Oral Rehabil 1993;20:19-31.

12. Asad T, Watkinson AC, Huggett R. The effect of disinfection procedures on flexural properties of denture base acrylic resin. J Prosthet Dent 1992;68:191-195.

13. Ma T, Johnson H, Gordon GE. Effects of chemical disinfectants on the surface characteristics and color of denture resins. J Prosthet Dent 1997;77:197-204.

14. Rosaspina S, Salvatorelli G, Anzanel D, Bovolenta R. Effect of microwave radiation on Candida albicans. Microbios 1994;78:55-59.

15. Dixon D, Breending LC, Faler TA. Microwave disinfection of denture base materials colonized with Candida albicans. J
Prosthet Dent 1999;81:207-214.

16. Banting DW, Hill SA. Microwave disinfection of dentures for the treatment of oral candidiasis. Spec Care Dentst 2001;21:48.

17. Sanders JL, Levin B, Reitz PV. Comparison of the adaptation of acrylic resin cured by microwave energy and conventional water bath. Quintessence Int 1991;22:181-186.

18. Consani RLX, Domiti SS, Rizzatti Barbosa CM, Consani S. Effect of commercial acrylic resins on dimensional accuracy of he maxillary denture base. Braz Dent J 2002;13:57-60.

19. Wolfaardt J, Cleaton-Jones P, Fatti P. The influence of processing variables on dimensional changes of heat-cured poly(methyl methacrylate). J Prosthet Dent 1986;55:518525.

20. Burns DR, Kazanoglu A, Moon PC, Gunsolley JC. Dimensional stability of acrylic resin materials after microwave sterilization. Int J Prosthodont 1990;3:489-493.

Accepted September 3, 2003 